[総説]

\title{
放射線照射香辛料に関する官能検査
}

\author{
千葉悦子 ${ }^{1)}$, 飯塚友子 ${ }^{1)}$, 市川まりこ ${ }^{1)}$, 鵜飼光子 ${ }^{2)}$, 菊地正博 ${ }^{3)}$, 小林泰彦 ${ }^{1), 3}$ * \\ 1) 食のコミュニケーション円卓会議 \\ 2) 北海道教育大学 († 040-8567 北海道函館市八幡町 1-2) \\ 3) 国立研究開発法人量子科学技術研究開発機構（广 370-1292＼cjkstart群馬県高崎市綿貫町 1233）
}

\section{Study on sensory test of irradiated spices}

\author{
Chiba, Etsuko ${ }^{1)}$, Iizuka Tomoko ${ }^{1)}$, Ichikawa Mariko ${ }^{1)}$, Ukai Mitsuko ${ }^{2)}$, \\ Kikuchi Masahiro ${ }^{3)}$ and Kobayashi Yasuhiko ${ }^{1), 3) *}$ \\ ${ }^{1)}$ Roundtable for Food Communication \\ ${ }^{2)}$ Hokkaido University of Education, 1-2, Hachiman-cho, Hakodate-shi, Hokkaido 040-8567, Japan \\ ${ }^{3)}$ National Institutes for Quantum and Radiological Science and Technology, 1233 Watanuki- \\ machi, Takasaki, Gunma 370-1292, Japan
}

Key words: irradiated spices（照射香辛料）, sensory test（官能検査）, pepper（コショウ), curry（カレー）, food thickener（とろみ調整剂）

\section{はじめに}

放射線照射により非加熱で殺虫・殺菌ができる ので，放射線照射した香辛料は国際的に広く流通 する ${ }^{1,2)}$ が，日本では許可されていない。日本で 食品照射の実用化が進まない理由の一つは, リスク の管理機関や評価機関，研究者，事業者，一般市民 との間に打けるリスクコミュニケーションの不足と 考えられる ${ }^{3)}$ 。また, 食品照射が理解されない理由 として，国民の不安や国民的合意の不足が指摘され る。しかし, 馬鈴著以外の食品への照射が食品衛生 法で禁止されているので, 日本では照射食品につい て体験的に知る機会がそしく，理解の促進が困難 で，不安が消えない。そこで食のコミュニケーショ ン円卓会議（以下，円卓会議と略す）の有志は, 種々の食品での照射による外観や食味への影響の有 無について，官能検査により比較を重ねた。その様 子を広く知らせて，より良いリスクコミュニケー

*連絡先 : kobayashi.yasuhiko@qst.go.jp
ションを推進したいと考えた。

照射した香辛料の香り成分である精油に関する研究 は，1990 年頃に打茶の水女子大学や原研で行われ た ${ }^{4)}$ 5)。お茶大の小林彰夫らの研究では, 黒コショ ウの粉末を過熱水蒸気殺菌する場合, 精油成分は著 しく減少し，かつ，バランスが崩れるが，放射線を $32 \sim 35 \mathrm{kGy}$ 照射しても非照射との差は認められな かったと報告された。このように，機器分析では照 射した香辛料についての報告があり，「高圧水蒸気 による加熱殺菌法では香りが大幅に減少し色調が 変化するなどの問題がある」 ${ }^{6)}$ とされているが, 官 能検査の報告一特に，香辛料を使った料理での報告 一は見当たらない。そこで, 日本で比較的よく使わ れる香辛料について, 官能検査でも照射殺菌品は過 熱水蒸気殺菌品との比較で違い一色の違い, 香りや 風味や辛味等の強弱，香りや風味の質的相違一があ るか，明らかにしたい。また，カレ一等，加熱する 料理に香辛料を入れた場合も，この様な違いがある か，明らかにすることを目指した。

さらに，香辛料さえ得られれば，実験室や特別な 
機器がなくても追試可能な, 上記比較に適するレシ ピや条件を探し，放射線照射の特長について体験的 な理解を広めることにより, リスクコミュニケー ションの一助にしたいと考えた。

\section{（1）カレーでの照射殺菌品と過熱水蒸気殺菌品と の比較 : その 1}

\section{目的}

カレーという，香辛料を入れて長く加熱する料理 の場合, 照射殺菌品は過熱水蒸気殺菌品との比較で 香りや風味等の強弱, 香りや風味の質的変化がある かを明らかにする。

\section{実験方法}

試料の調製：ターメリック，カルダモン，コリアン ダー, シナモン, 赤唐辛子について「未処理品」と 「過熱水蒸気殺菌品」を得て, 「未処理品」の一部を 日本原子力研究開発機構高崎量子応用研究所 (現 量子科学技術研究開発機構高崎量子応用研究所。以 下，高崎研と略す）で Co-60 の $\gamma$ 線を $10 \mathrm{kGy}$, 室 温で照射した。なお，赤唐辛子は粉末品を照射した が, 他の香辛料は原体で照射後, 電気式回転式フー ドミルで粉砕後, 目開き $1 \mathrm{~mm}$ のメッシュでパスし た物を仕上がり品とした。

カレーの調理法 : 高校家庭科教科書のチキンカレー のレシピ 7) を基に表 1 の材料とした。同じサイズ

表 1 チキンカレー材料分量 その 1

\begin{tabular}{lc}
\hline \multicolumn{1}{c}{ 材料 } & 分量 $(1$ 人分 $)$ \\
\hline 鶏もも肉（骨付き） & 2 本 $(120 \mathrm{~g})$ \\
たまねぎ & $70 \mathrm{~g}$ \\
しょうが & $5 \mathrm{~g}$ \\
にんにく & $5 \mathrm{~g}$ \\
トマト & $100 \mathrm{~g}$ \\
赤唐辛子 & 少々 \\
シナモン & 少々 \\
カルダモン & 少々 \\
ターメリック & $0.4 \mathrm{~g}$ \\
コリアンダー & $1.0 \mathrm{~g}$ \\
塩 & $4 \mathrm{~g}$ \\
サラダ油 & $7.5 \mathrm{~mL}$ \\
水 & $100 \mathrm{~mL}$ \\
\hline 元のレシピの香辛料小さじ 1 を $2 \mathrm{~g}$ と換算
\end{tabular}

の 2 つの中華鍋で料理し，片方は照射殺菌の香辛 料，もう片方は過熱水蒸気殺菌の香辛料を用いた。

官能検査：2009 年 11 月 25 日, 円卓会議会員とそ の知人，合計 11 名が殺菌方法を伏せるブラインド 検査で比較した。2 点試験法では， 2 点の内どちら かを選ばせるが，パネルが素人であることも考慮 し，どうしても選べない場合を想定して「変わらな い」という選択肢も用意した。

\section{結果および考察}

官能検查結果は表 2 に示すように, 照射品のカ レーの方が過熱水蒸気殺菌品のカレーより, 香りや 風味が強かった。「試食前の香りの違い」は，2点 嗜好試験検定表によると，「1\%の危険率で有意差あ り」で，照射品の方が，香りが強かった。「試食中 の風味の違い」は，「5\%の危険率で有意差あり」で 照射品の方が, 風味が強かった。ただし，筆者はブ ラインド検査ではなかったので，厳密には危険率は 高くなる。それでも，筆者は予備実験も含めて，香 りや試食中の風味, 特に辛味について, 毎回違いを 感知したので，筆者の分もカウントして問題ないと 考える。なお，パネルは官能検査に慣れている人 も，慣れていない人も，「違いを感知しにくく，官 能検査員から外された」という人も含まれていた。 このようなパネルで, 上記の差が認められたという ことは, ぐつぐつと煮込んで加熱するカレーであっ ても, 照射殺菌品の方が過熱水蒸気殺菌品より香り や風味が明らかに強いと判断できた。なお，今回は 初めての比較であり，質問項目に「辛味」の項目を 入れなかったので,「風味」に辛味も含む。以降, 「風味」は，試食した時に主に鼻で感じるものとす る。そして，「辛味」の項目を独立して入れること にした。

必ずしも照射殺菌品が好まれるとは限らないよう であり，質的な違いがあるかもしれないが，それは 今後の課題となった。

今回，色については，質問紙の評価項目に入れな かった。色の差異に惑わされる先入観で, 香りや風 味の判定に影響がないようにするためである。わず かな色の違いを感じる敏感な人がいたかもしれない 程度の違いであり，ほとんど同じようであった。た だし，香辛料自体の色としては，ターメリックと赤 唐幸子は一目瞭然の違いがあった ${ }^{8)}$ 。 
表 2 カレー試食結果（カレーでの照射殺菌品と過熱水蒸気殺菌品との比較その 1)

$\mathrm{O}$ ：照射した香辛料で作ったカレー $\mathrm{P}$ ：加熱殺菌の香辛料で作ったカレー

処理方法を伏せて，O・Pの符号を付けブラインド試験をした

1. 試食前に香りの違いはありますか? 該当するものに一つ○を付けてください。

・吕の方が香りが強い 10 名 その程度は（わずか 5 名 少し 4 名 かなり 1 名）

・Pの方が香りが強い 0 名

・変わらない 1 名

2. 試食中，風味の違いはありますか? 該当するものに一つ○を付けてください。

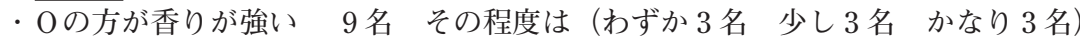

・Pの方が香りが強い 1 名 その程度は（わずか 1 名 少し 0 名 かなり 0 名）

・変わらない 1 名

3. 試食中, 風味についての好みは次のどれに該当しますか?

・ Oの方が好き 7 名 その程度は（わずか 1 名 少し 2 名 かなり 3 名 無回答 1 名）

・Pの方が好き $\quad 0$ 名

・ O と $\mathrm{P}$ の風味の違いは感じるが，好みの優劣はつけられない。 2 名

・O と Pの風味の違いが感じられないので，好みも優劣はつけられない。1名

·無回答 1 名

4. あなたは, カレーは好きですか?

好き 8 名 普通 2 名 嫌い 0 名 嫌いというわけではないが「辛さ」が苦手 0 名 無回答 1 名

反省事項として，「塩気が強過ぎて，香辛料の比 較がしにくい。」クミンも入れる方が一般的」が あった。

\section{（2）カレーでの照射殺菌品と過熱水蒸気殺菌品と の比較 : その 2}

\section{目的}

「その $1 」$ の反省事項や，その後の予備的な実験 の結果を踏まえ, 照射殺菌品は過熱水蒸気殺菌品と の比較で香りや風味や辛味等の強弱や質的違いがあ るか明らかにする。加えて, それらの相違があると して, リスクコミュニケーションに適した，違いを 感知しやすいレシピを開発する。

\section{実験方法}

試料の調製: 新規に, ターメリック，カルダモン, コリアンダー, シナモン, 赤唐辛子, クミン, ロリ エの葉について「未処理品」と「過熱水蒸気殺菌品」 を得, 「未処理品」の一部に高崎研で Co-60 の $\gamma$ 線を $10 \mathrm{kGy}$ ，室温で 2013 年 7 月に照射した。今回は，口 リエの葉以外は, 粉末になった物を照射後, $-25^{\circ} \mathrm{C}$ の冷凍庫に保存し, 同年 9 月下旬に取り出し, 高崎 研で各香辛料の重さを測定した。

カレーの調理法 : 表 3 の材料とした。調理の省力化
表 3 チキンカレー材料分量 その 2

\begin{tabular}{|c|c|}
\hline 材 料 & 分 量 \\
\hline 䊿もも肉（骨・皮なし） & $400 \mathrm{~g}$ \\
\hline ローストオニオン (エバラ) & $90 \mathrm{~g}(1$ 袋 $)$ \\
\hline しょうが & $10 \mathrm{~g}$ \\
\hline にんにく & $10 \mathrm{~g}$ \\
\hline $\begin{array}{l}\text { 完熟カットトマト（デルモンテ· } \\
\text { 輸入者キッコーマン) }\end{array}$ & $\begin{array}{l}240 \mathrm{~g} \\
(3 / 5 \text { パック強 })\end{array}$ \\
\hline 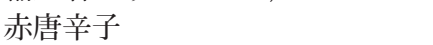 & $0.80 \mathrm{~g}$ \\
\hline シナモン & $1.00 \mathrm{~g}$ \\
\hline カルダモン & $1.00 \mathrm{~g}$ \\
\hline ターメリック & $3.00 \mathrm{~g}$ \\
\hline コリアンダー & $8.00 \mathrm{~g}$ \\
\hline クミン & $2.00 \mathrm{~g}$ \\
\hline ロリエの葉 & 1 枚 \\
\hline 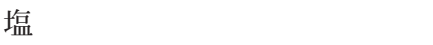 & $2.60 \mathrm{~g}$ \\
\hline サラダ油 & $15 \mathrm{~mL}$ \\
\hline 水 & $200 \mathrm{~mL}$ \\
\hline
\end{tabular}

を図り，今回は生のトマトやたまねぎでなく半調理 品を用いた。

官能検査： 2013 年 10 月 1 日に「カフェ円卓，放射 線（非加熱）殺菌した香辛料を使うカレーの食味体 験 」9) を開催し，18名（円卓会議会員とその関係者。 官能検査未経験者も含む。）が参加した。殺菌方法 を伏せるために器に印を付けたカレー（過熱水蒸気 
殺菌品）を基準として, 別の印のカレー（照射殺菌 品）を判定するブランインド検査で，5段階評価し た。

\section{結果および考察}

官能検查結果は表 4 に示すように，照射品の方 が，辛味や風味が強かった。「辛味の強さ」は，2 点嗜好試験検定表によると,「5\%の危険率で有意差 あり」で, 照射品の方が, 辛味が強かった。「その1」 と同様，筆者はブラインド検査ではなかったので, 厳密には危険率は高くなるが，筆者は予備実験も含 め，特に辛味について，毎回違いを明確に感知した ので，筆者の分も入れて問題ないと考える。

材料分量についての反省事項は，照射品の方に青 臭さを感じた人がいたことである。これは，コリア ンダーの量が多過ぎたのが原因と考える。コリアン ダーは単位体積当たりの重さが少ない香辛料で，そ れを勘案しなかったのが主原因と考える。また,「そ の1」に比べて加熱時間が短かったので，香気成分 の揮発が少なかったこともあろう。さらに，筆者に よる予備実験では，鼻がそれほざ鋭敏ではない上 に, 調理を長時間して感度が鈍り, 気付かなかった ことによる。

「風味の種類が異なる場合, どう異なるかお書き ください」の記述闌に数名が書き込んだ。「赤（照 射品）の方が繊細な香りがするような感じでした。」 「赤 (照射品) の方がすっきりした辛味あり。とい う感想から，質的な違いを感知した人が複数いたと 考えられる。

「その1」後の予備的な実験（詳細は省略）は, カレー全体に対する香辛料の量が少ないレシピで, 過熱水蒸気殺菌品に比べ照射殺菌品の方が，香りや 風味が強くて「香りが立つ」という質的な違いが分 かりやすかった。ただし，「香辛料が少な過ぎて売 り物にならない」という感想があったので，香辛料 の量を増やした一般的な味の場合はどうか？，「そ の $2 」 の$ 試験を実施して確かめた。上記の結果を総 合すると，殺菌方法による質的な違いがある可能性 が高いと考える。

「その $1 」 よ り$ 簡便な調理で香辛料の殺菌方法の 違いを感知できるという点では，より良いレシピを 開発できたと考える。
表 4 カレーでの照射殺菌品と過熱水蒸気殺菌品と の比較その 2

\begin{tabular}{llc}
\hline & & 人数 \\
\hline 試食, 風味 & 強い & 3 \\
強さ & やや強い & 8 \\
& 変わらない & 4 \\
& やや弱い & 2 \\
& 弱い & 1 \\
\hline 試食, 風味 & 好ましい & 1 \\
好み & やや好ましい & 10 \\
& 変わらない & 5 \\
& やや劣る & 2 \\
& 劣る & \\
\hline 試食, 辛味 & 強い & 6 \\
強さ & やや強い & 7 \\
& 変わらない & 4 \\
& やや弱い & 1 \\
& 弱い & \\
\hline 総合評価 & 好ましい & 3 \\
& やや好ましい & 9 \\
& 変わらない & 5 \\
& やや劣る & 1 \\
& 劣る & \\
\hline
\end{tabular}

被験者 17 名

殺菌方法を伏せた過熱水蒸気殺菌品を基準として，照 射殺菌品を判定するブラインド検査

網掛けの部分は, 「照射殺菌品の方が強い」と統計的 有意差ありで示された。

あなたはカレーが好きですか？

好き：15名 普通：2名 嫌い: 0名

嫌いというわけではないが，「辛さ」が苦手：1名

\section{（3）未処理品を対照とした照射殺菌品と過熱水蒸 気殺菌品との, 香辛料自体の比較}

\section{目的}

カレーでの香辛料の比較では, 香辛料数種類が混 然一体であったので，今回は 1 種類ずつの比較をす る。

筆者が調べたカレーの材料では，コショウのない ものがほとんどであったので，（1）（2）のカレーに コショウを入れなかったが，日本でよく使われるコ

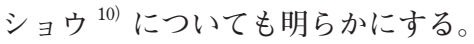

未処理品を対照として比較し, 色・香り ·風味 · 
辛味等につて, 照射殺菌品は過熱水蒸気殺菌品より 違いが少ないか, 明らかにする。併せて, 照射殺菌 の特長を体験的に理解する方法を探る。

\section{実験方法}

試料の調製：「(2) カレーでの照射殺菌品と過熱水 蒸気殺菌品との比較 : その $2 」$ の香辛料と共に, 黒 コショウ, 白コショウ, オレガノ, タイムも同様に 用意し，合計 11 種類とした。

官能検査 $: 2013$ 年 8 月 3 日に「カフェ円卓 $\cdots$ 食品 照射の基礎を楽しく学びませんか」 ${ }^{11)}$ を開催し, 14 名（円卓会議会員以外も含む）が検査した。未 処理品を対照として, 予め知らせた照射殺菌品, 過 熱水蒸気殺菌品をそれぞれ比較し，7段階で評価し た。

香辛料の色については，ほとんどの人が 11 種類
について検査した。

試食しての風味については, シナモン, クミン, 赤唐辛子, 黒コショウの 4 種類に絞って検査した。 筆者の予備実験にて殺菌方法の違いが感知しやすい ものから選んだ。各香辛料を爪楊枝等を使い，目視 で同量ずつ口に入れるという方法とした。

\section{結果および考察}

色についての結果は表 5 に, 風味は表 6 に示す。 どの香辛料も, 色・風味両方について, 過熱水蒸気 殺菌品より照射殺菌品の方が, 未処理品を対照とし て「変わらない」とした人が多かった。

特に赤唐辛子とターメリックは, 著しい色の違い があった。これは「(1) カレーでの照射殺菌品と過 熱水蒸気殺菌品との比較その $1 」 て ゙$ 用いた香辛料と 同様であった。黒コショウと赤唐辛子については

表 5 未処理品を対照とした過熱水蒸気殺菌と照射殺菌の各香辛料の判定結果…色

\begin{tabular}{|c|c|c|c|c|c|c|c|}
\hline & $\begin{array}{c}\text { 非常に } \\
\text { 薄い }\end{array}$ & 薄い & $\begin{array}{l}\text { 少し } \\
\text { 薄い }\end{array}$ & $\begin{array}{c}\text { 変わら } \\
\text { ない }\end{array}$ & $\begin{array}{l}\text { 少し } \\
\text { 濃い }\end{array}$ & 濃い & $\begin{array}{c}\text { 非常に } \\
\text { 濃い }\end{array}$ \\
\hline シナモンA & & & & 1 & 11 & 1 & \\
\hline シナモン B & & & & 13 & 1 & & \\
\hline クミン A & & 1 & 8 & 1 & 3 & 1 & \\
\hline クミン B & & & 1 & 12 & 1 & & \\
\hline 黒コショウA & & & & 9 & 4 & & \\
\hline 黒コショウ B & & & & 12 & 1 & & \\
\hline 赤唐辛子 A & & & & & & 9 & 5 \\
\hline 赤唐辛子 B & & & 1 & 13 & & & \\
\hline オレガノ A & & & 2 & 2 & 5 & 2 & \\
\hline オレガノ B & & & & 12 & & & \\
\hline 白コショウ A & & & & 6 & 6 & & \\
\hline 白コショウ B & & & & 12 & & & \\
\hline タイムA & 1 & 2 & 2 & & 6 & 2 & \\
\hline タイム B & & & 2 & 12 & & & \\
\hline カルダモン A & & 2 & 3 & 8 & & & \\
\hline カルダモン B & & & & 11 & 1 & 1 & \\
\hline コリアンダーA & & & 2 & 5 & 5 & & \\
\hline コリアンダー B & & & 1 & 8 & & 2 & \\
\hline ターメリック A & & & & 1 & 5 & 6 & 1 \\
\hline ターメリック B & & & & 8 & 5 & & \\
\hline ロリエの葉 A & & & & & 1 & 5 & 4 \\
\hline ロリエの葉 B & & 1 & 1 & 8 & 4 & & \\
\hline
\end{tabular}

被験者：14 名

$\mathrm{A}:$ 過熱水蒸気殺菌品, B: 照射殺菌品

処理については予め告知し，未处理品を基準として判定

数字は人数を表す。合計が少ない部分は, 未回答のため。 
表 6 未処理品を対照とした各香辛料の風味の判定結果

\begin{tabular}{|c|c|c|c|c|c|c|c|}
\hline & $\begin{array}{c}\text { 非常に } \\
\text { 弱い }\end{array}$ & 弱い & $\begin{array}{l}\text { 少し } \\
\text { 弱い }\end{array}$ & $\begin{array}{c}\text { 変わら } \\
\text { ない }\end{array}$ & $\begin{array}{l}\text { 少し } \\
\text { 強い }\end{array}$ & 強い & $\begin{array}{c}\text { 非常に } \\
\text { 強い }\end{array}$ \\
\hline シナモン A & 1 & 3 & 2 & 6 & 2 & & \\
\hline シナモン B & 1 & 1 & & 11 & & & \\
\hline クミン A & 1 & 2 & 6 & 5 & & & \\
\hline クミンＢ & 1 & 1 & 3 & 8 & 1 & & \\
\hline 黒コショウA & 1 & & 7 & 5 & & & \\
\hline 黒コショウ B & 1 & & 1 & 9 & 2 & & \\
\hline 赤唐辛子 A & & 3 & 5 & 4 & 1 & 1 & \\
\hline 赤唐辛子 B & & & 1 & 11 & 2 & & \\
\hline
\end{tabular}

被験者：14名

A: 過熱水蒸気殺菌品, B: 照射殺菌品

処理については予め告知し，未処理品を基準として判定

数字は人数を表す。合計が少ない部分は，未回答のため。

14 名中 8 名が「加熱蒸気殺菌より照射殺菌の方が, 風味が強い」，4名が「同じ」と読み取れる結果と なり，ある程度の傾向が出たと考える。

風味の比較を行った 4 種類の香辛料については, 色と組み合わせて二次元マップで表示した（図 1〜 4)。グラフの横軸は「色」の「薄い〜濃い」につい て, 縦軸は「風味」の「強い〜弱い」についてであ り，対応する座標に 14 名が各自 1 枚ずつシールを
貼った。シールが原点の位置にあれば未処理品と差 がないことを意味する。

図の左側の過熱水蒸気殺菌品では, 色も風味も未 処理品からは大きく変化しているが, 右側の照射殺 菌品では比較的原点の付近にまとまり, 色・風味共 に変化が小さいことが見て取れる。照射殺菌品が官 能検査でも未処理品と近いことが理解しやすかっ た。

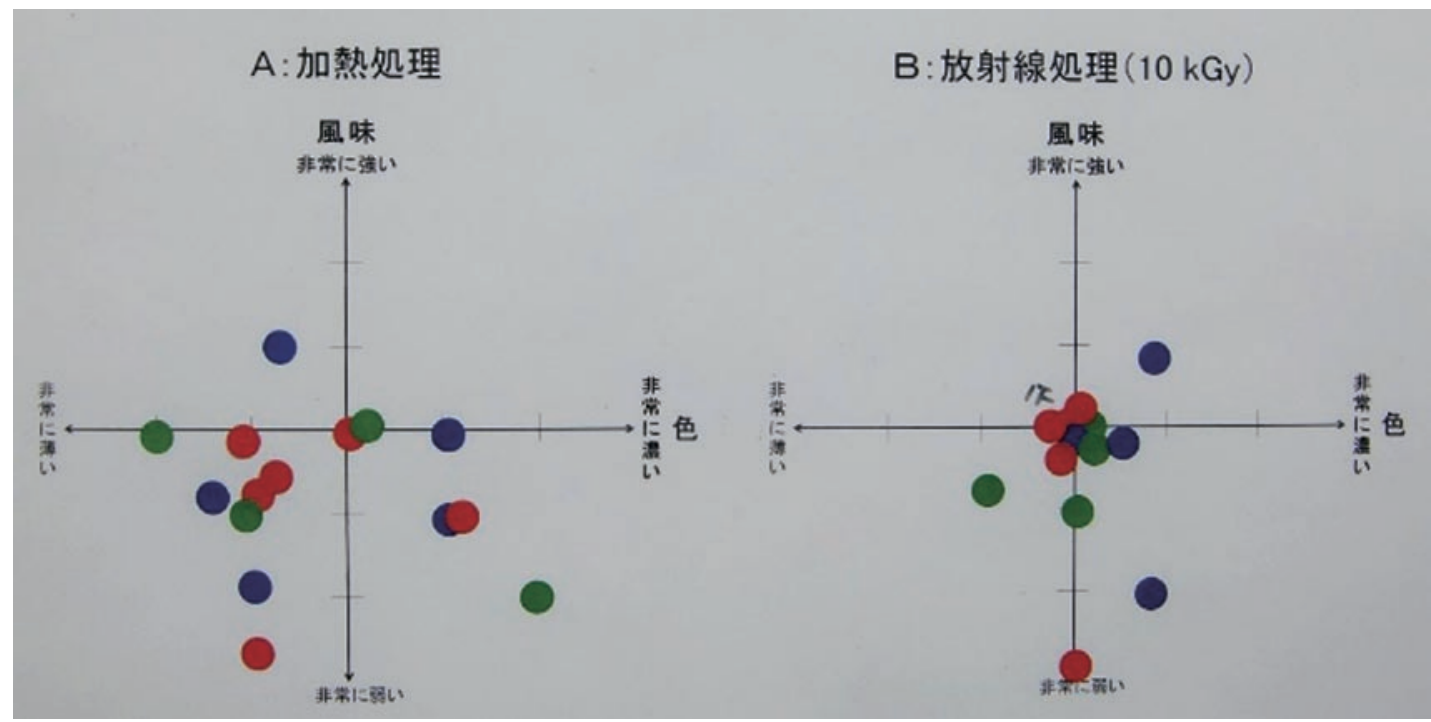

図 1 クミンの未処理品を対照とした過熱水蒸気殺菌（左）と照射殺菌（右）の色（横軸）と風味（縦軸） の判定結果 


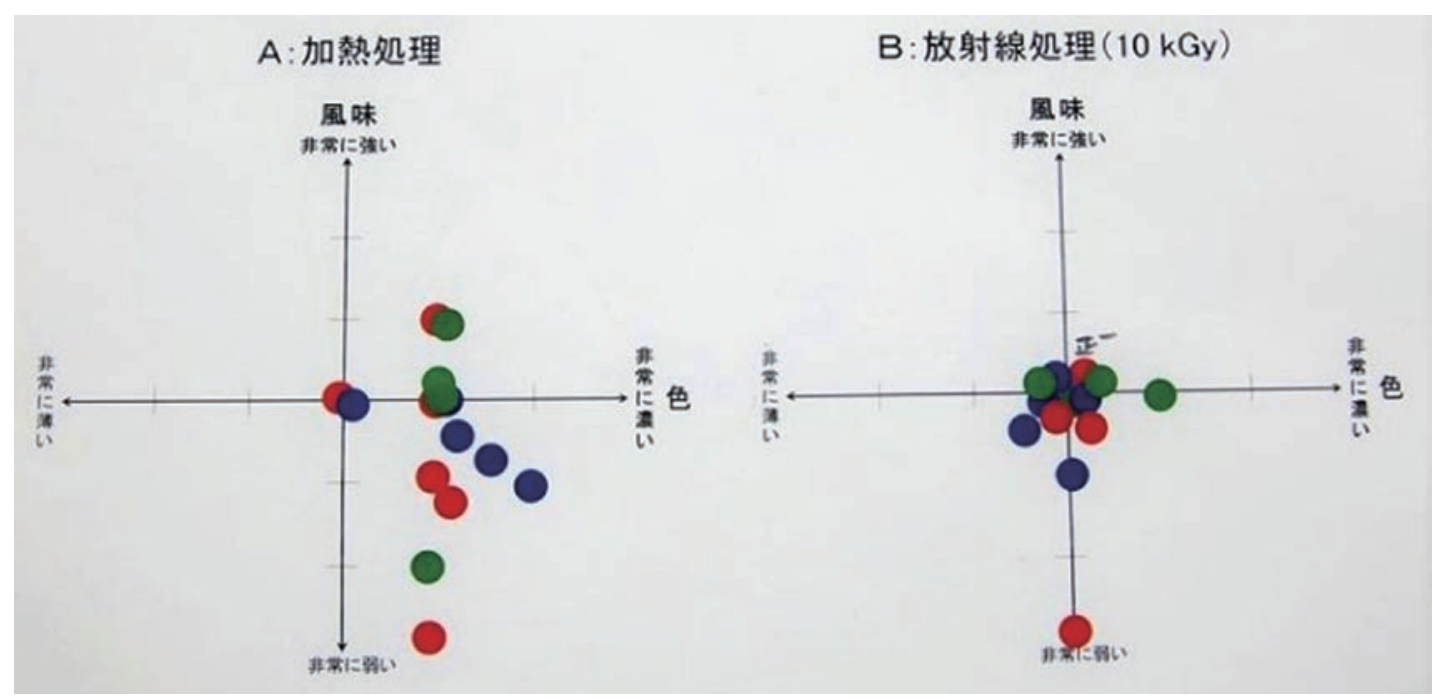

図 2 シナモンの未処理品を対照とした過熱水蒸気殺菌（左）と照射殺菌（右）の色（横軸）と風味（縦軸） の判定結果

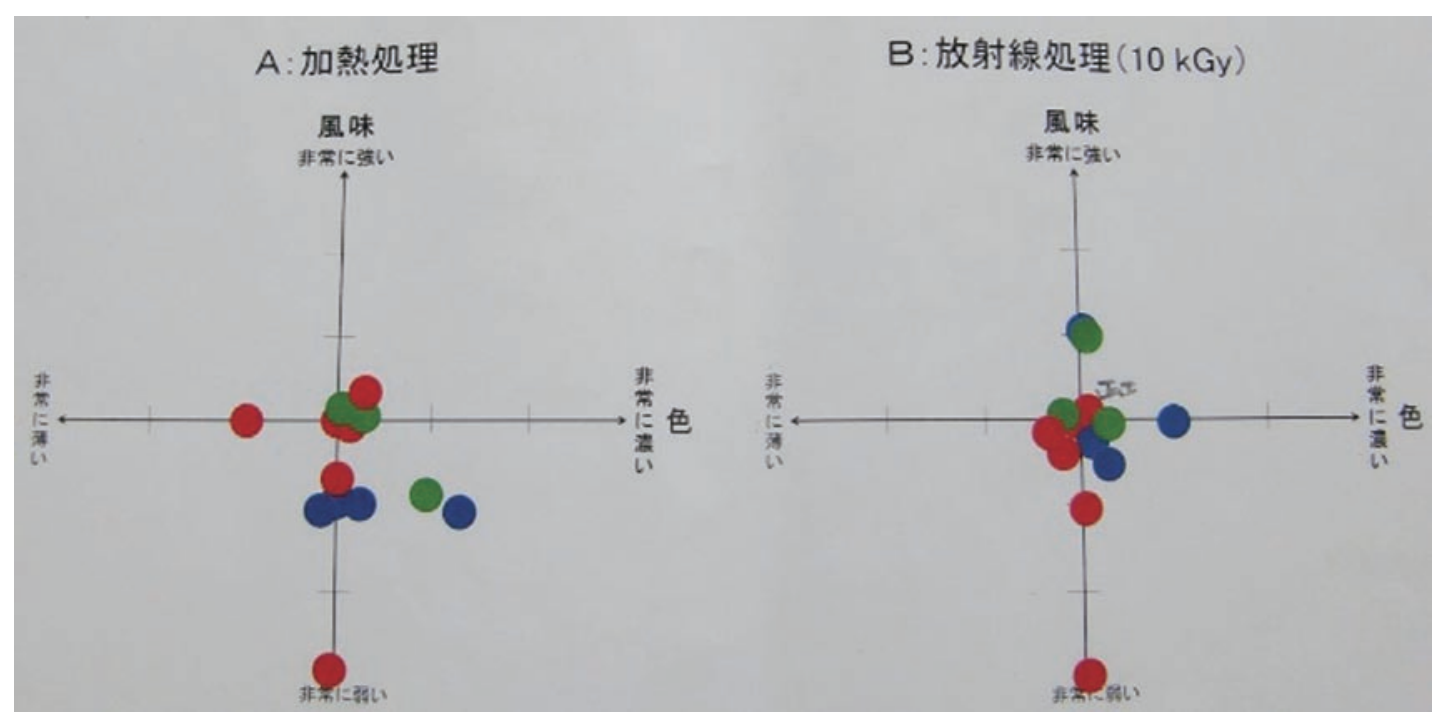

図 3 黒コショウの未処理品を対照とした過熱水蒸気殺菌（左）と照射殺菌（右）の色（横軸）と風味（縦軸） の判定結果 


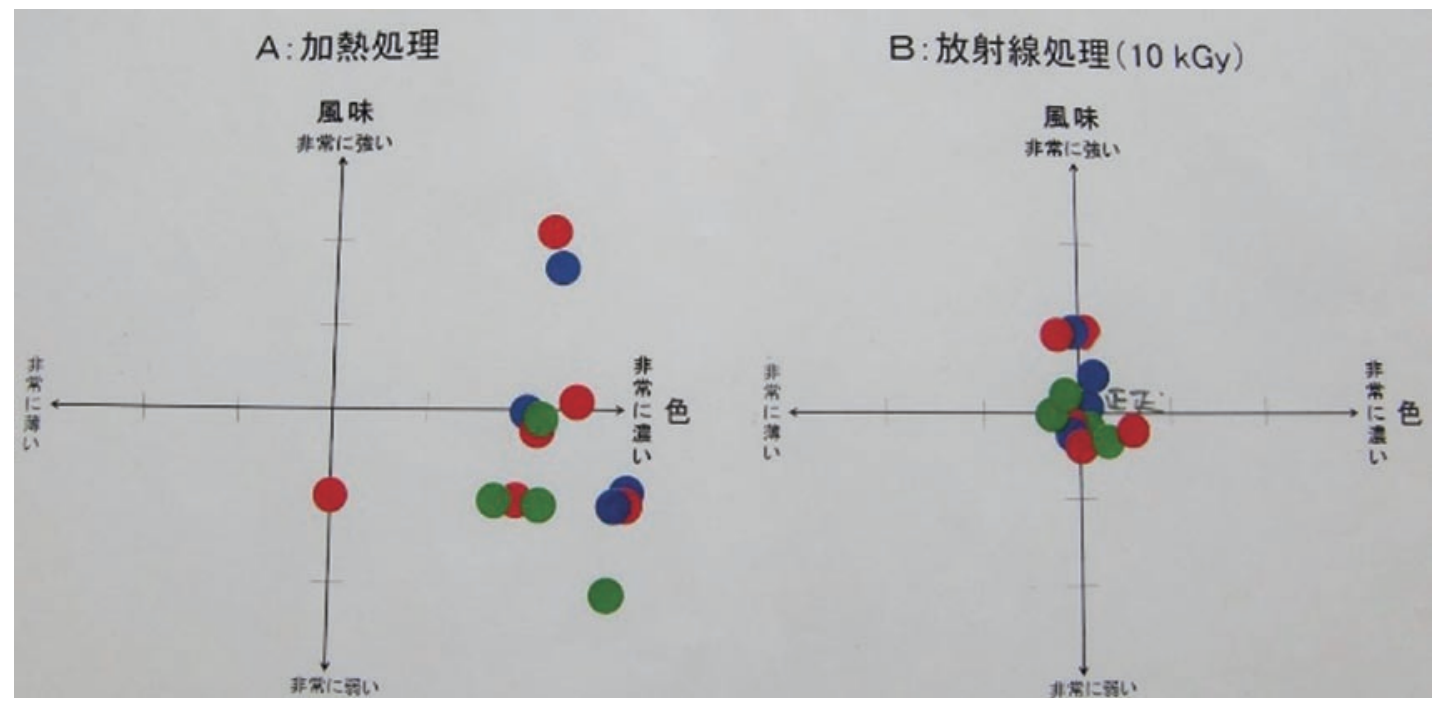

図 4 赤唐辛子の未処理品を対照とした過熱水蒸気殺菌（左）と照射殺菌（右）の色（横軸）と風味（縦軸） の判定結果

（4）カレー以外での照射殺菌品と過熱水蒸気殺菌 品との香辛料の比較 : その 1 (トマトピュー レにオレガノと黒コショウを混ぜて比較)

\section{目的}

「(3) 未処理品を対照とした照射殺菌品と過熱水蒸 気殺菌品との, 香辛料自体の比較」では, 目視で同 量ずつ口に入れる比較であり, 悠密に同じ量とは言 いにくいので，量を揃え，かつ，衛生的に行う方法 を求める。以前, キャベツ炒めにコショウを入れて 比較した際, コショウが均一に混ざらず, 殺菌方法 の違いを感知出来なかった。そこで, スープで試し たところ，香辛料は水に浮沈し均一にならない。均 一に分散させるためには, とろみの付いたポター ジュのようなタイプを用いる必要がある。予備実験 として, 市販の離乳食のホワイトソース煮を使った ところ, 予想に反しうま味や香料等が強過ぎて, 香 辛料の微妙な違いを感知しにくかった。今回は夏に 開催する，調理室のない施設に打けるイベントなの で, 衛生を第一とし，うま味調味料等の入っていな い瓶詰のトマトピューレを使う方法を検討する。

\section{実験方法}

試料の調製：「(3) 未処理品を対照とした照射殺菌 品と過熱水蒸気殺菌品との, 香辛料自体の比較」の 際に調達した，オレガノと黒コショウを用いた。1 びん $200 \mathrm{~g}$ のトマトピューレ，オレガノ $0.50 \mathrm{~g}$ ，黒 コショウ $0.25 \mathrm{~g}$ をボウルに入れて混ぜた。

官能検査 :「(3) 未処理品を対照とした照射殺菌品 と過熱水蒸気殺菌品との, 香辛料自体の比較」と同 日に，同じメンバーと筆者，合計 15 名で実施した。 殺菌方法を伏せるブラインド検査で,「外観」と「風 味の好みに」ついては 5 段階評価，「風味の強さ」 は 7 段階評価とした。

\section{結果および考察}

結果を表 7 に示す。統計的な有意差はないが，照 射殺菌品の方が過熱水蒸気殺菌品より風味が強い傾 向があった。

一番の反省点は，塩も，トマトピューレ以外のう ま味もなく，おいしくなかったことである。少なめ に塩を加えると，だいぶ食べやすかったことだろ う。これは，調理室を使えれば可能である。また， 「香辛料の量を少なくした方が良い」という感想も あった。 
（5）カレー以外での照射殺菌品と過熱水蒸気殺菌 品との香辛料の比較:その 2 (カブのポタージュ に黒コショウを混ぜる)

\section{目的}

日本でよく使われる黒コショウについて，量を揃 えて，殺菌方法の違いによる差異があるか，調べ る。

表 7 トマトピューレ入り黒コショウ・オレガノの 試験結果

\begin{tabular}{|c|c|c|}
\hline & & 人数 \\
\hline $\begin{array}{l}\text { 外観 } \\
\text { 色 }\end{array}$ & $\begin{array}{l}\text { 濃い } \\
\text { やや濃い } \\
\text { 変わらない } \\
\text { やや薄い } \\
\text { 薄い }\end{array}$ & $\begin{array}{l}3 \\
9 \\
3\end{array}$ \\
\hline $\begin{array}{l}\text { 試食, } \\
\text { 風味の強さ } \\
\text { 後味も比較 } \\
\text { してください }\end{array}$ & $\begin{array}{l}\text { 非常に強い } \\
\text { 強い } \\
\text { やや強い } \\
\text { 変わらない } \\
\text { やや弱い } \\
\text { 弱い } \\
\text { 非常に弱い }\end{array}$ & $\begin{array}{l}4 \\
5 \\
4 \\
2\end{array}$ \\
\hline $\begin{array}{l}\text { 試食, } \\
\text { 風味の好み }\end{array}$ & $\begin{array}{l}\text { 好ましい } \\
\text { やや好ましい } \\
\text { 変わらない } \\
\text { やや劣る } \\
\text { 劣る }\end{array}$ & $\begin{array}{l}3 \\
4 \\
4 \\
4\end{array}$ \\
\hline $\begin{array}{l}\text { トマトが } \\
\text { 好きですか？ }\end{array}$ & $\begin{array}{l}\text { 好き } \\
\text { 普通 } \\
\text { 嫌い }\end{array}$ & $\begin{array}{r}12 \\
3\end{array}$ \\
\hline $\begin{array}{l}\text { 黒コショウが } \\
\text { 好きですか？ }\end{array}$ & $\begin{array}{l}\text { 好き } \\
\text { 普通 } \\
\text { 嫌い }\end{array}$ & $\begin{array}{r}10 \\
5\end{array}$ \\
\hline $\begin{array}{l}\text { オレガノが } \\
\text { 好きですか？ }\end{array}$ & $\begin{array}{l}\text { 好き } \\
\text { 普通 } \\
\text { 嫌い } \\
\text { 分からない }\end{array}$ & $\begin{array}{l}2 \\
7 \\
1 \\
5\end{array}$ \\
\hline
\end{tabular}

被験者：12名

殺菌方法を伏せた過熱水蒸気殺菌品を基準として照射 殺菌品を判定するブラインド検査

\section{実験方法}

試料の調製：「(3)未処理品を対照とした照射殺菌品 と過熱水蒸気殺菌品との，香辛料自体の比較」の際 と同じ黒コショウを用いた。カブのポタージュは, カブの白い部分，玉ねぎ，バター，ごく少量の「味 の素 丸鶏がらスープの素」，牛乳を材料として，ミ

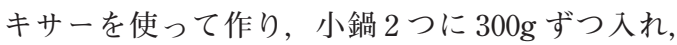
各殺菌処理した黒コショウを $0.10 \mathrm{~g}$ ずつ入れてよく 混ぜた。

官能検査 : 2014 年 2 月 11 日に円卓会議会員 4 名で,

表 8 カブのポタージュ入り黒コショウの試験結果

\begin{tabular}{|c|c|c|}
\hline & & 人数 \\
\hline \multirow{5}{*}{$\begin{array}{l}\text { 試食, } \\
\text { 風味の強さ }\end{array}$} & 強い & \\
\hline & やや強い & 1 \\
\hline & 変わらない & 3 \\
\hline & やや弱い & \\
\hline & 弱い & \\
\hline \multirow{5}{*}{$\begin{array}{l}\text { 試食, } \\
\text { 風味の好み }\end{array}$} & 好ましい & \\
\hline & やや好ましい & 2 \\
\hline & 変わらない & 2 \\
\hline & やや劣る & \\
\hline & 劣る & \\
\hline \multirow{5}{*}{$\begin{array}{l}\text { 試食, 辛味 } \\
\text { 強さ }\end{array}$} & 強い & \\
\hline & やや強い & 1 \\
\hline & 変わらない & 3 \\
\hline & やや弱い & \\
\hline & 弱い & \\
\hline \multirow[t]{2}{*}{ 後味 } & 強い & 2 \\
\hline & 変わらない & 2 \\
\hline \multirow[t]{5}{*}{ 総合評価 } & 好ましい & \\
\hline & やや好ましい & 2 \\
\hline & 変わらない & 2 \\
\hline & やや劣る & \\
\hline & 劣る & \\
\hline
\end{tabular}

被験者：4名

予め知らせた過熱水蒸気殺菌品を基準にして照射殺菌 品を判定 
予め知らせた過熱水蒸気殺菌品を基準に照射品を判 定した。

\section{結果および考察}

結果は表 8 に示す。殺菌方法の違いが明確には出 ていないが，主にパネルの質によると考える。殺菌 方法の違いを感知しなかった 2 名中, 1 名は 60 歳 代で味について自信が持てないということであっ た。もう1名は，官能検査で何回も「香辛料が薄 くて違いが分かりにくい」と述べ, 日頃からスパイ シーな料理を好む人であった。

筆者は，他の野菜やいものポタージュでも試した 予備実験を含めて, 毎回, 辛味の違いを明確に感知 したので，訓練されたパネルであれば，統計的に有 意な差が出るだろうと考える。ただし, 誰もが違い を感知するには, 香辛料の濃度を高低 2 種類にする といった工夫が必要と考える。

今回, 白コショウでなく黒コショウを用いた理由 は, 白コショウの風味がもともと悪いと感じる人が いることである。しかし，今回のパネルの中には， 香辛料単体で比較した際に白コショウについて質的 な違いを明確に感知した人がいるので，それも含め て比較するために, 手作りポタージュを用いるより 簡便に比較できる方法を探したいと考えた。

\section{（6） カレー以外での照射殺菌品と過熱水蒸気殺菌 品との香辛料の比較 : その 3 (とろみ調整剤 を用いた方法)}

\section{目的}

香辛料の量を揃えて，殺菌方法の違いによる差異 があるか否かを調べる，比較的簡便で，だれもが実 施しやすい方法を開発する。水にとろみ調整郕（以 下，とろみ剂と略す）を溶かして香辛料を混ぜたも のは，正直なところ，まずいので，スープにして食 ベやすくしようと，簡便な市販品を用いる方法も取 り入れ，適するか検討する。

\section{試料の調製}

\section{実験方法}

香辛料：「(3) 未処理品を対照とした照射殺菌品と 過熱水蒸気殺菌品との, 香辛料自体の比較」の際と 同じクミン，赤唐辛子，白・黒コショウを用いた。
1 回目の実験は冷凍庫から 2015 年 3 月 31 日に取り 出して量った物を同年 4 月 8 日に用い，2 回目の実 験は同年 9 月 2 日に取り出し, 同年 9 月 8 日に用い た。

とろみ剤：香辛料を分散させるため，介護用とろみ 剤のキューピー「とろみファイン」(原材料：デキ ストリン，増粘多糖類，グルコン酸ナトリウム）を 用いた。

1 回目: クミン ‥水道水 $510 \mathrm{~g}$ に「とろみファイン」 5 袋（1.5 g × 5) を混ぜたもの（「とろみ液」と記 す) $240 \mathrm{~g}$ に，クミン $0.48 \mathrm{~g}$ ずつよく混ぜる。予備 実験において, クミンは分散状態が安定しなかった ので，他の香辛料に使うとろみ剂濃度の約 2 倍とし た。白・黒コショウ…水道水 $600 \mathrm{~g}$ に「とろみファ

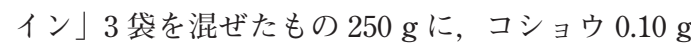
ずつ混ぜる。

赤唐辛子…2 段階希勫とした。まず，「とろみ液」 $50.0 \mathrm{~g}$ に赤唐辛子 $0.10 \mathrm{~g}$ ずつ混ぜる。そこから $15.0 \mathrm{~g}$ 取り出し，「とろみ液」 $235 \mathrm{~g}$ を混ぜる。

スープ入り白コショウ…沸騰した水道水 $600 \mathrm{~g}$ に味 の素「フォン・ド・ボー」 2 個 $(6 \mathrm{~g} \times 2)$ を混ぜ たもの $250 \mathrm{~g}$ に, 白コショウ $0.10 \mathrm{~g}$ ずつ混ぜる。

2 回目 : 白・黒コショウ, 赤唐辛子, スープ入り白 コショウについては，1回目と同様とした。スープ 入り黒コショウについて，白コショウと同様に調製 した。なお，クミンの比較は行わなかった。

官能検査 : 1 回目は 2015 年 4 月 8 日に北海道教育 大学で, 同大学生と教員, 計 16 名で行った。ティー スプーン 1 さじずつ口に入れ, 過熱水蒸気殺菌品を 基準として照射殺菌品を判定するブラインド検査と した。風味や味について 5 段階で評価した。なお， 後味については，クミンは口に入れてから 30 秒後, その他は 1 分後とした。2 回目は 2015 年 9 月 8 日 に高崎研にて，職員等 10 名で行った。1回目とほ ぼ同様だが，ティースプーンを使い，目視で同量ず つ口に入れた。

\section{結果および考察}

赤唐辛子，白・黒コショウについては，照射殺菌 品の方が過熱水蒸気殺菌品に比べて, 風味や辛味が より強いという傾向の結果であった。

クミンの結果は表 9 に示す。クミンは結果にバラ つきが大きかった。予備実験として，2015 年 3 月 
表 9 とろみ液入りクミンの試験結果

\begin{tabular}{llc}
\hline & & 人数 \\
\hline 試飲, & 強い & 3 \\
風味の強さ & やや強い & 4 \\
& 変わらな & 3 \\
& やや弱い & 5 \\
& 弱い & 1 \\
\hline 試飲, & 好ましい & 3 \\
風味の好み & やや好ましい & 3 \\
& 変わらない & 7 \\
& やや劣る & 2 \\
& 劣る & 1 \\
\hline 試飲, 味 & 強い & 4 \\
强さ & やや強い & 2 \\
& 変わらない & 2 \\
& やや弱い & 8 \\
& 弱い & \\
\hline 30秒後の & 強い & 2 \\
後味 & やや強い & 1 \\
風味や味の & 変わらない & 5 \\
強さ & やや弱い & 6 \\
& 弱い & 2 \\
\hline クミンが & 好き & 2 \\
好きですか & 普通 & 4 \\
& 嫌い & 1 \\
& 分からない & 9 \\
\hline
\end{tabular}

被験者：16 名

殺菌方法を伏せた過熱水蒸気殺菌品を基準にして 照射殺菌品を判定（ブラインド検査）

に円卓会議会員が予め試料の殺菌方法を知らせる方 法で判定した結果に比べて, 照射殺菌品は風味や味 が強いという傾向が出なかった。それは，「クミン が好きですか」の問いに「クミンを単独で食べたこ とがないので分からない」と答えた人が比較的多い 事や, パネルのほとんどが学生で, 香辛料の食経験 が少ないことによると考える。

白・黒コショウとスープ入り白・黒コショウの結 果は表 10 に示す。スープ入り白コショウの風味の 強さは, 統計的有意差が 1 回目, および $1 \cdot 2$ 回目 の合計にあった。さらに, 白コショウの辛味の強 さは, 有意差が, 水とスープの両方において, 1 ・ 2 回目の合計にあった。白コショウの風味は, 水よ りスープで照射殺菌品が好まれる傾向である。これ はスープの方が, 本当の料理に近く, 安心して飲み
やすいことによろう。ただし，「フォン・ド・ボー」 の風味があまり好きでない人には試飲しにくかっ た，と感想から分かった。

前述の問題点はあるが，スープになるよう市販品 を用いることで，再現性の高い簡便な実験になると 考える。また，この「フォン・ド・ボー」には香料 が含まれず，香辛料の香りや風味の違いを感知しや すいと考える。

赤唐辛子の結果は表 11 に示す。赤唐辛子の辛味 は，重量当たりでコショウよりさらに強く，2段階 希釈する必要があるほどである。そうして薄くなっ た分，風味の違いを感知するのが難しかったのだろ うと推測する。

赤唐辛子と白・黒コショウは辛味が特に強いの で，適度と感じる濃度に個人差が大きく，感想欄に 「胃までヒリヒリ」と記す人もいれば，「薄くてよく 分からない! 風味の比較というょり感度検査の気 分」「濃度を上げた方がわかりやすい」と書く人も いた。今後, 濃度を 2 種類にすれば，ほとんど全員 が「照射殺菌品の方が風味や辛味が強い」と感じ, 風味の質的な違いも感知しやすいだろう。

今後は, 出来るだけ新しい香辛料で試したい。 - $25^{\circ} \mathrm{C}$ の冷凍庫に香辛料を保存したとはいえ，香 辛料を得てから， 2 年程度経過したので，香気成分 が低減し，比較しにくかった可能性があるからだ。

今回行った新規官能検查方法が有効だろうと仮定 して, 照射殺菌品と過熱水蒸気殺菌品を比較した が，パネルの信頼度や有効性についての問題は残 る。たとえば食品企業の敏感なパネルに協力頂ける として, ガスクロマトグラフィーでの分析と同様の 結果であれば，有効であると検証できるだろう。し かし，外部の協力が難しそうな上に， 円卓会議で多 くのパネルを訓練するのは難しいので，今後は，香 辛料の濃度が異なる「とろみ液」で, 違いを感知で きるか否かも併せて検查することから始める方法が 考えられる。濃度の違いを感知したパネルだけで, とろみ液に入った香辛料の殺菌方法の違いを調心゙ て，検査方法の有効性を検証できるのではないかと 考える。また，におい識別装置で有効性は検証でき るかもしれない。

\section{まとめ}

「放射線殺菌に比べて過熱水蒸気殺菌では香辛料 
表 10 水のとろみ液・スープのとろみ液入り白・黒コショウの過熱水蒸気殺菌と照射殺菌の比較, $1 \cdot 2$ 回 目の結果

\begin{tabular}{|c|c|c|c|c|c|c|c|c|c|c|c|}
\hline & & \multirow{2}{*}{\multicolumn{6}{|c|}{ 白コショウ }} & \multirow{2}{*}{\multicolumn{4}{|c|}{ 黒コショウ }} \\
\hline & & & & & & & & & & & \\
\hline & & \multicolumn{3}{|c|}{ 水のとろみ液 } & \multicolumn{3}{|c|}{ スープのとろみ液 } & \multicolumn{3}{|c|}{ 水のとろみ液 } & \multirow{2}{*}{$\begin{array}{c}\text { スープの } \\
\text { とろみ液 } \\
\frac{2 \text { 回 }}{}\end{array}$} \\
\hline & & 1 回 & 2 回 & 合計 & 1 回 & 2 回 & 合計 & 1 回 & 2 回 & 合計 & \\
\hline \multirow{5}{*}{$\begin{array}{l}\text { 風味 } \\
\text { 強さ }\end{array}$} & 強い & 2 & 1 & 3 & 3 & 3 & 6 & 4 & & 4 & \\
\hline & やや強い & 6 & 6 & 12 & 9 & 4 & 13 & 4 & 6 & 10 & 5 \\
\hline & 変わらない & 6 & 1 & 7 & 4 & 2 & 6 & 1 & 2 & 3 & 3 \\
\hline & やや弱い & 1 & 2 & 3 & & 1 & 1 & 6 & 2 & 8 & 2 \\
\hline & 弱い & 1 & & 1 & & & & 1 & & 1 & \\
\hline \multirow{5}{*}{$\begin{array}{l}\text { 風味 } \\
\text { 好み }\end{array}$} & 好ましい & & & & 2 & 2 & 4 & 1 & & 1 & 1 \\
\hline & やや好ましい & 4 & 3 & 7 & 6 & 5 & 11 & 4 & 7 & 11 & 4 \\
\hline & 変わらない & 6 & 4 & 10 & 7 & 2 & 9 & 7 & 2 & 9 & 3 \\
\hline & やや劣る & 5 & 3 & 8 & 1 & 1 & 2 & 3 & 1 & 4 & 2 \\
\hline & 劣る & 1 & & 1 & & & & 1 & & 1 & \\
\hline \multirow{5}{*}{$\begin{array}{l}\text { 辛味 } \\
\text { 強さ }\end{array}$} & 強い & 2 & 3 & 5 & 3 & 2 & 5 & 4 & 3 & 7 & 1 \\
\hline & やや強い & 9 & 4 & 13 & 8 & 5 & 13 & 4 & 5 & 9 & 3 \\
\hline & 変わらない & 2 & 1 & 3 & 3 & 2 & 5 & 1 & 1 & 2 & 3 \\
\hline & やや弱い & 2 & 2 & 4 & 1 & 1 & 2 & 6 & 1 & 7 & 2 \\
\hline & 弱い & 1 & & 1 & 1 & & 1 & 1 & & 1 & \\
\hline \multirow{5}{*}{$\begin{array}{l}1 \text { 分後の } \\
\text { 後味, } \\
\text { 辛味 } \\
\text { 強さ }\end{array}$} & 強い & 1 & 2 & 3 & 4 & 2 & 6 & 3 & 2 & 5 & 1 \\
\hline & やや強い & 9 & 3 & 12 & 3 & 3 & 6 & 3 & 5 & 8 & 1 \\
\hline & 変わらない & 3 & 4 & 7 & 7 & 5 & 12 & 6 & 1 & 7 & 6 \\
\hline & やや弱い & 2 & 2 & 4 & 2 & & 2 & 4 & 1 & 5 & \\
\hline & 弱い & 1 & & 1 & & & & & & & 1 \\
\hline
\end{tabular}

被験者：1回目 16 人, 2 回目 10 人

数字は人数を表す。合計が少ない部分は，未回答のため。

殺菌方法を伏せた過熱水蒸気殺菌品を基準にして

照射殺菌品を判定 (ブラインド検査)

網掛けの部分は，「照射殺菌品の方が強い」と統計的有意差ありで示された。

の香りや風味が減少し色調が変化する」ことを，円 卓会議会員らは五感を使って体験的に理解できた。 しかも，煮込んで加熱するカレーであっても，放射 線殺菌品の方が香りや辛味等が強い。条件によって は，訓練されたパネルばかりでなくても，統計的な 有意差が出るほどの殺菌方法による違いが認められ た。このような条件の要素について, 特別な実験施 設がない場合を想定して，次に示す。

・パネルが慣れ親しむ香辛料やその他の材料を選
ぶ。

・香辛料は古くないものを用いる。

・カレー等で食味について比較する場合, 外観に左 右されないよう，ターメリックのように殺菌方法 による色の違いが大きいものは，少なめに使う。 ・香辛料の量を揃えて厳密に比較する場合は，香辛 料が分散するよう，ポタージュのようなものにす る。その簡便な方法として, 介護用とろみ剂も有 効だろう。 
表 11 とろみ液入り赤唐辛子の試験結果

\begin{tabular}{|c|c|c|c|}
\hline & & $\begin{array}{l}1 \text { 回目 } \\
\text { 人数 }\end{array}$ & $\begin{array}{l}2 \text { 回目 } \\
\text { 人数 }\end{array}$ \\
\hline \multirow{5}{*}{$\begin{array}{l}\text { 試飲, } \\
\text { 風味の強さ }\end{array}$} & 強い & 2 & 3 \\
\hline & やや強い & 7 & 2 \\
\hline & 変わらない & 4 & 3 \\
\hline & やや弱い & 2 & 2 \\
\hline & 弱い & 1 & \\
\hline \multirow{5}{*}{$\begin{array}{l}\text { 試飲, } \\
\text { 風味の好み }\end{array}$} & 好ましい & 1 & \\
\hline & やや好ましい & 4 & 4 \\
\hline & 変わらない & 7 & 4 \\
\hline & やや劣る & 2 & 2 \\
\hline & 劣る & 2 & \\
\hline \multirow{5}{*}{$\begin{array}{l}\text { 試飲，辛味 } \\
\text { 強さ }\end{array}$} & 強い & 3 & 4 \\
\hline & やや強い & 4 & 2 \\
\hline & 変わらない & 5 & 3 \\
\hline & やや弱い & 3 & 1 \\
\hline & 弱い & 1 & \\
\hline \multirow{5}{*}{$\begin{array}{l}1 \text { 分後の } \\
\text { 後味 } \\
\text { 風味や味の } \\
\text { 強さ }\end{array}$} & 強い & 3 & 2 \\
\hline & やや強い & 4 & 4 \\
\hline & 変わらない & 4 & 3 \\
\hline & やや弱い & 4 & 1 \\
\hline & 弱い & 1 & \\
\hline \multirow{3}{*}{$\begin{array}{l}\text { 赤唐幸子が } \\
\text { 好きですか？ }\end{array}$} & 好き & 6 & 3 \\
\hline & 普通 & 6 & 7 \\
\hline & 嫌い & 4 & \\
\hline
\end{tabular}

被験者：1回目 16 人, 2 回目 10 人 殺菌方法を伏せた過熱水蒸気殺菌品を基準にして 照射殺菌品を判定（ブラインド検査）

・ポタージュ等に香辛料を混ぜる場合，香料の入ら ない材料を選び，また，うま味や塩味が強過ぎな い味付けにする。

・辛味を感知しやすかったり好んだりする濃度は, 個人差が大きいので， 2 種類の濃度を用意する。 放射線殺菌の長所を体験的に納得して頂きたい場 合は, 色と風味, 両方の比較を行い, 2 次元マップ に表すと効果的である。試食や試飲だけでは違いを 感知しにくい人もいるからだ。五感を使い納得する と, 数字を伴う説明である「放射線照射による殺菌 は, 菌数を減らす能力が高い」といった，いわば理 系の話に耳を傾ける気力が高まると推測する。この ような体験を糸口にした理解の促進は, リスクコ ミュニケーションの一助となろう。

\section{要 旨}

「香辛料は，照射殺菌に比べて過熱水蒸気殺菌で は香りが減少し色調が変化する」ことを，官能検査 により種々の条件で確かめた。加熱調理のカレーで あっても，照射殺菌品は過熱水蒸気殺菌品より「試 食前の香り」や「試食しての辛味」が統計的な有意 差を伴い強かった。料理でなく香辛料自体で比較 し, 赤唐辛子, 白・黒コショウは, 照射殺菌品の方 が，風味や辛味がより強い傾向であった。さらに， 赤唐辛子やターメリックの過熱水蒸気殺菌品は，未 処理品との色の違いが非常に大きく，照射品は小さ かった。そこで, 色と風味の比較を 2 次元マップ に表すと，照射品は未処理品に近いことが一目瞭然 で，放射線殺菌の長所が納得しやすく，リスクコ ミュニケーション推進に効果的であると分かった。 また，香辛料は水に浮沈するので，香辛料の量を厳 密に揃える比較には，香辛料の分散が必要と分かっ た。それには，ポタージュや介護用とろみ剤が有効 であろう。とろみ剤を水に溶かして香辛料を分散さ せると, 白コショウの辛味は, 統計的な有意差を伴 い，照射殺菌品の方が過熱水蒸気殺菌品より強かっ た。ただし，照射品の風味の方が好まれるとは限ら ず，風味は強弱だけでなく質的な違いも感知される 場合があると考えられた。

\section{謝 辞}

試料の調製や官能検查にご協力くださいました皆 様に深く感謝申し上げます。

\section{参考文献}

1）等々力節子. 各国の食品照射の現状（2013 年 後半 2015 年前半)。食品照射. 50, p.47-58 (2015)

2 ）久米民和．世界に打ける食品照射実用化の現状 食品照射。49，p.115-116（2014）

3 ) 小林泰彦. 新しい形の食品照射のコミュニケー ション活動．食品照射４49，p.116-118（2014）

4 ）伊藤 均. 香辛料の放射線殺菌効果. 食品照射. 49, p.87-89 (2014)

5 ）社団法人 日本原子力産業協会. 香辛料の放射 線殺菌効果と実用化の必要性について．食品照 射 Q\&Aハンドブック p.41-44（2007） 
http://www.jaif.or.jp/ja/sangyo/qa-handbook. pdf (2016.8.14)

6 ）社団法人 日本原子力産業協会. わが国での食 品照射研究の経緯と今後の課題について. 食品 照射 Q\&Aハンドブック p.20-26（2007）

7 ) 竹中恵美子・春日キスヨ監修。これからの家庭 基礎一あたらしい生活を求めて。 p.80一橋出版 (2003)

8 ）食のコミュニケーション円卓会議. ガーリック 通信 5 号「華麗なるカレー worldへようこそ!!」 (2010 年 2 月 5 日発行)

http://food-entaku.org/garlicweb/garlic-5.pdf

9 )「カフェ円卓…食品照射の基礎を体験で学ぶ
放射線 (非加熱) 殺菌した香辛料を使うカレー の食味体験」

http://food-entaku.org/cafe-entaku-20131001. pdf

10）日本香辛料研究会. 主な国別スパイス消費ラン キング．スパイス何でも小事典．講談社 p.136 (2011)

11）「カフェ円卓…食品照射の基礎を楽しく学びま せんか」

http://food-entaku.org/cafe-entaku-20130803. pdf

(2016 年 9 月 8 日受理) 